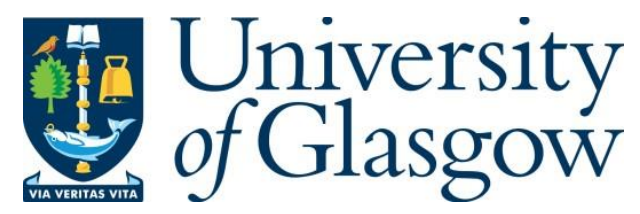

Papathoma, T., Ferguson, R., Littlejohn, A. and Coe, A. (2016) Making the Production of Learning at Scale more Open and Flexible. In: L@S '16: Proceedings of the Third ACM Conference on Learning @ Scale, Edinburgh, UK, 25-26 Apr 2016, pp. 273-276. ISBN 9781450337267.

There may be differences between this version and the published version. You are advised to consult the publisher's version if you wish to cite from it.

(C) The Authors 2016. This is the author's version of the work. It is posted here for your personal use. Not for redistribution. The definitive Version of Record was published in the Proceedings of the Third ACM Conference on Learning @ Scale, Edinburgh, UK, 25-26 Apr 2016, pp. 273-276. ISBN 9781450337267. https://doi.org/10.1145/2876034.2893432.

http://eprints.gla.ac.uk/185562/

Deposited on: 30 April 2019

Enlighten - Research publications by members of the University of Glasgow http://eprints.gla.ac.uk 


\section{Making the production of learning at scale more open and flexible}

Tina Papathoma

The Open University

Milton Keynes, MK7 6AA, UK

Tina.Papathoma@open.ac.uk

Rebecca Ferguson

The Open University

Milton Keynes, MK7 6AA, UK

Rebecca.Ferguson@open.ac.uk

\section{Allison Littlejohn}

The Open University

Milton Keynes, MK7 6AA, UK

Allison.Littlejohn@open.ac.uk

\author{
Angela Coe \\ The Open University \\ Milton Keynes, MK7 6AA, UK \\ Angela.Coe@open.ac.uk
}

\begin{abstract}
Professional learning is a critical component of the ongoing improvement, innovation and adoption of new practices that support learning at scale. In this context educators must learn how to apply digital technologies and work effectively in digital networks. This study examines how higher education professionals adapted their practice to enable more open and flexible work processes. A case study carried out using Activity

Theory showed that teams involved in the development of a module all need access to a range of expertise both practical and academic. At each stage, they need to be clear about the learning outcomes of the module, the responsibilities of each team and its constraints. Teams need to be willing to agree ways to shift those constraints in order to develop a module effectively.
\end{abstract}

\section{Author Keywords}

Online Courses; Professional Learning; Activity Theory; Innovation; Case Study

Permission to make digital or hard copies of part or all of this work for not made or distributed for profit or commercial advantage and that copies bear this notice and the full citation on the first page. Copyrights for third-party components of this work must be honored. For all other for third-party components of this uses, contact the Owner/Author

Copyright is held by the owner/author(s)

@@S 2016, April 25-26, 2016, Edinburgh, Scotland Uk

http://dx.doi.org/10.1145/2876034.2893432

\section{ACM Classification Keywords \\ Management}

\section{Background}

The rapid changes in society and working life that have taken place during the past few decades have increased interest in workplace learning and made lifelong 


\begin{tabular}{|c|c|}
\hline Community & Roles \\
\hline $\begin{array}{l}5 \text { 'Academic' } \\
\text { members } \\
\text { (Module } \\
\text { team) }\end{array}$ & $\begin{array}{l}\text { Writing } \\
\text { module } \\
\text { content }\end{array}$ \\
\hline $\begin{array}{l}1 \text { Module } \\
\text { Chair } \\
\text { (Module } \\
\text { team) }\end{array}$ & $\begin{array}{l}\text { Guiding } \\
\text { academics \& } \\
\text { liaising with } \\
\text { LTS }\end{array}$ \\
\hline $\begin{array}{l}1 \text { Curriculum } \\
\text { manager } \\
\text { (Module } \\
\text { team) }\end{array}$ & $\begin{array}{l}\text { Project } \\
\text { management } \\
\text { of academics } \\
\text {,liaising with } \\
\text { different } \\
\text { sections of } \\
\text { the } \\
\text { community }\end{array}$ \\
\hline $\begin{array}{l}4 \text { 'Learning } \\
\text { and Teaching } \\
\text { Solutions' } \\
\text { (LTS) } \\
\text { members }\end{array}$ & $\begin{array}{l}\text { Implementing } \\
\text { innovative } \\
\text { ways of } \\
\text { supporting } \\
\text { module } \\
\text { production }\end{array}$ \\
\hline $\begin{array}{l}3 \\
\text { Management } \\
\text { members }\end{array}$ & $\begin{array}{l}\text { Ensuring } \\
\text { everyone } \\
\text { remains on } \\
\text { schedule }\end{array}$ \\
\hline \multicolumn{2}{|c|}{$\begin{array}{l}\text { Table 1. Roles of the } \\
\text { community }\end{array}$} \\
\hline
\end{tabular}

learning and learning in the workplace a necessity for organisations, nations and individuals [1]. Rapid learning needs to take place in new environments such as learning at scale, not only through intentional formal training [2] such as workshops but also through learning on the job, which may not be recognised as 'learning'. Different types of knowledge require different types of learning.

'Integrative Pedagogy' provides a way of bringing together key elements of learning and the development of expertise [3]. It consists of four tightly integrated elements: theoretical knowledge (formal), practical knowledge (tacit), regulative knowledge (individuals decide how they learn) and sociocultural knowledge. The last three types of knowledge are not explicit. Learning is embodied in the development of better practices and skills as well as in the creation of social and material innovations nurtured by progressive problem solving and the intention to integrate conceptual understanding with problem solving [1].

This study explores how the professional practice of educators changes when using innovative tools to adapt the process of authoring an online module. The study's research questions relate to professionals' use of digital tools in online education, the importance of learning on the job, and integrative pedagogy.

- How does the professional practice of a module team at a university change when module production becomes more open and allows flexibility?

- What are the enablers and the barriers to those changes?

\section{Methodology}

A case study was conducted within an Open University (OU) module team. The team deals with learning at scale, using systems that are structured to deal with thousands of learners and hundreds of educators, so change usually takes time. The aim of the study was to explore and trial new ways of producing module content (i.e. course content) and examine how the professional practice of a team changes when there is more flexibility in ways of working together with access to innovative tools for module design. A case study design was used because it enabled researchers to answer explanatory questions about contemporary events without manipulating behaviour [4].

The unit of analysis for the study was the activity system of a community of people (see Table 1) contributing towards an advanced level (equivalent to final-year undergraduate) Science Module requiring 600 study hours. This case was chosen because the conventional method of module production had been disrupted, prompting the professionals to change their practice. They authored content directly on an open online platform, whereas the previous practice had been to use a word processor and then pass content to colleagues for multiple editing phases.

The study used the terms of Activity Theory (AT) in order to identify and analyse changes in practice associated with the production of the online module. According to AT, human activities are complex, socially situated phenomena. A key idea is that activities are outcome-oriented and driven by project goals and motives related to past experience. There may be multiple motives within an activity system as subjects negotiate the relationship of their motives with the 


\begin{tabular}{|l|l|}
\hline Past & Present \\
\hline $\begin{array}{l}\text { Linear, } \\
\text { Fragmented, } \\
\text { Individual } \\
\text { process }\end{array}$ & $\begin{array}{l}\text { Dynamic, } \\
\text { Synchronous, } \\
\text { Transparent, } \\
\text { Collaborative } \\
\text { process }\end{array}$ \\
\hline $\begin{array}{l}\text { Limited view } \\
\text { of module } \\
\text { development }\end{array}$ & Holistic view \\
\hline $\begin{array}{l}\text { Ideas } \\
\text { forgotten }\end{array}$ & $\begin{array}{l}\text { Ideas } \\
\text { captured }\end{array}$ \\
\hline $\begin{array}{l}\text { Deadlines lost } \\
\text { Table 2. Changes in Practice }\end{array}$ & $\begin{array}{l}\text { Work grows } \\
\text { dynamically }\end{array}$ \\
\hline $\begin{array}{l}\text { Academics } \\
\text { were more } \\
\text { passive }\end{array}$ & $\begin{array}{l}\text { Academics } \\
\text { were active } \\
\text { monitor }\end{array}$ \\
\hline $\begin{array}{l}\text { Management } \\
\text { mound process }\end{array}$ & $\begin{array}{l}\text { Management } \\
\text { could } \\
\text { monitor the } \\
\text { process more } \\
\text { easily }\end{array}$ \\
\hline
\end{tabular}

emergent motives of the community. Such differing motives produce tensions in the activity system [5]

The components and relationships of the activity system represent the situation in which members (subjects i.e. the module team) work on an object (i.e. module production) or problem space, transforming it into an outcome (i.e. change of professional practice) using tools (i.e. open platform). The tool-mediated action may be constrained or enabled by implicit and explicit rules (i.e. university regulations and faculty guidelines related to university standards) and the broader social context (community i.e. the teams represented in Table 1.) within which the activity takes place. Labour (i.e. the tasks of the module team) is divided among the community members (roles).

\section{Sample}

As shown in Table 1, the module team of this study consisted of the Academics, the Module Chair and the Curriculum manager. The focus is on this team because the module team, and especially the academics within it, had taken more central roles in the module production and this changed the activity of the system and the motives not only of the module team but also of the rest of the community.

Three groups (academics, management, 'Learning and Teaching Solutions' group) and two individuals - the Module Chair (lead academic) and Curriculum Manager - made up different sections of the Activity Systems' community and were interviewed in order to identify the changes in the motives of each team in their setting. There was a focus on how action is mediated with the use of new tools. The study followed the ethical guidelines of the British Educational Research Association (BERA).

\section{Analysis}

Thematic analysis [6] was used to identify the components and relationships of the 'activity system' community. The transcribed text of interviews was coded using codes from the activity system - object, tools, rules and division of labour. Emergent themes were added to these, including 'roles' of the community (subtly related to division of labour) and 'tensions' between roles and rules of the activity system. NVivo was used to study how interviewees talked about the changes in practice associated with the new models of production, with an emphasis on aspects that enabled or hindered these changes.

This analysis revealed changes in professional practice between conventional module development (past) and the new process (present). These are summarised in Table 2. Enablers and barriers to changes in practice are summarised in Table 3.

\section{Discussion}

The change of practice was an evolutionary process for the module team. It gave them opportunities to learn on the job, rather than through formal training, and to gain skills quickly.

The study provided insights into improved practices that could be used by teams developing learning at scale using new tools and approaches. Meeting new challenges helped community members to develop collaborative skills. The open platform that the teams used, provoked tensions between the Academic grouping and the LTS grouping, because historically 


\begin{tabular}{|l|}
\hline Enablers to change \\
\hline -Efficient, less time- \\
consuming process \\
-Production timeline as a \\
form of currency \\
-Affective impact of \\
freedom from systematic \\
constraints (rules). Rules \\
changed- from 'system \\
control' to 'people control' \\
-The open platform \\
enhanced creativity \\
\hline Barriers to change \\
\hline -Negative impact of LTS \\
role change \& \\
disagreement on end \\
product \& demotivation \\
-Achievement of change \\
of practice overlooked \\
-Process still termed \\
'module production'\& \\
entrenches cultural \\
expectations \\
- Tensions negotiated \\
within single teams \\
- Trust broke down when \\
project timeline changed \\
\& teams went back to \\
previous practice \\
-ownership of innovation \\
unclear \\
Table 3. Enablers\& Barriers \\
\end{tabular}

LTS had had more control of the final product than the Academics and the new roles on the platform were not clearly defined.

Using the terms of activity theory, the study found that a community needs to have access to a range of expertise associated with the object in order to reach the outcome. The outcome, the division of labour and the rules should all be clearly defined. The community needs to be prepared to change or amend the rules during the activity in order to reach an effective outcome.

In other words, teams contributing to the development of a course or module need to have access to a variety of practical and academic expertise. They should also be clear about the learning goals of the module, the responsibilities of each team, and its constraints. Teams need to work together on ways to deal with constraints in order to reach an effective outcome. This is challenging, because practices involving huge systems, structured to deal with large numbers of learners and educators take time to change.

\section{Conclusion}

Higher education is changing as it increasingly uses digital technologies to provide courses and therefore professionals in this area need to change their practice. This initial exploratory case study provides insights that can benefit teams who need to change their practice and work more flexibly in order to develop learning at scale. In particular, it identifies a need to define and make clear to everyone the intended outcome of module development, the division of labour and the constraints on the process. The findings of the study will inform further research into learning at scale and the ways in which large numbers of people can collaborate to create online courses and shift their practice from a face-to-face to an online environment.

\section{Acknowledgments}

We thank Doug Clow who provided helpful comments on versions of this document. We also thank Sam Smidt, Anne Jelfs, Sarah Bridgman and all the interviewees.

\section{References}

1. Päivi Tynjälä. 2008. Perspectives into Learning at the Workplace. Educational Research Review, 3:130-154.

2. Michael Eraut, Wendy Hirsh. 2007. The Significance of Workplace Learning for Individuals, Groups and Organisations. Skope Monographs, Oxford.

3. Päivi Tynjälä, David Gijbels. 2012. Changing World: Changing Pedagogy. In Transitions and Transformations in Learning and Education, Päivi Tynjälä, Marja-Leena Stenström, Marjatta Saarnivaara (Eds). Springer, 205-222.

4. Robert K. Yin. 2003. Case Study Research: Design and Methods 3rd ed., Sage Publications, Newbury Park.

5. Yrjö Engeström. 2005. Knotworking to create collaborative intentionality capital in fluid organizational fields. In Collaborative Capital: Creating Intangible Value. Michael M. Beyerlein, Susan T. Beyerlein, Frances A. Kennedy (Eds.) Elsevier, Amsterdam, 307-336.

6. Victoria Braun, Virginia Clarke 2006. Using thematic analysis in psychology. Qualitative Research in Psychology, 3,2: 77-101 